\title{
The comparison of calculation methods of gas demand in the installation with combi boilers
}

\author{
Andrzej Jedlikowski ${ }^{1, *}$, and Sebastian Englart ${ }^{1}$ \\ ${ }^{1}$ Wrocław University of Science and Technology, Faculty of Environmental Engineering, Department \\ of Air Conditioning, Heating, Gas Engineering and Air Protection, 4/6 Norwida st., 50-373 Wrocław, \\ Poland
}

\begin{abstract}
Combi boilers offer an economic alternative to individual single function gas boilers and instantaneous water heaters. These gas appliances allow for producing thermal energy for two heating purposes (space heating and hot water preparation). For this reason these compact and highly efficient devices are becoming increasingly popular in many residential buildings. The application of such heating systems often requires an adequate approach for determining the natural gas demand. The literature indicates several methods for this purpose, which often differ significantly. Differences in calculated results seem to be the main problem with these methods. Unfortunately, the selection of the above-mentioned gas appliances always causes overestimation of natural gas demand. This is mainly due to the fact that many calculation methods contain incorrect gas demand coefficients. Therefore, this paper presents various methods for estimating gas consumption for multi-family buildings. It provides discussion and analysis of various calculation methods for residential buildings equipped with two types of gas appliance. The performed analysis made it possible to indicate the most reliable methods of gas demand calculation.
\end{abstract}

\section{Introduction}

Residential buildings are characterised by energy demand linked mainly to the municipal needs, such as in the preparation of meals, supply of domestic hot water and space heating. One of the ways to meet these needs is through the use of gas appliances [1]. Typically, gas appliances such as gas cookers and gas cookers with oven, water heaters and gas-fired central heating boilers were used in older buildings [2]. In modernised or newly designed residential buildings, water heaters and boilers are very often replaced with combi boilers which allow for the implementation of the two listed living needs [3, 4]. These devices operate continuously, keeping the water circulation in the central heating system. When the flow occurs in the hot water installation, these devices automatically activate full heating power and heat the cold-water inlet to the required temperature parameters. Demand for heating power for such needs is usually higher than for space heating because water is

\footnotetext{
*Corresponding author: andrzej.jedlikowski@pwr.edu.pl
} 
heated in a continuous flow system [5-7]. According to Polish Regulations [8], provision of buildings with gas and installations should correspond to the needs and conditions resulting from the physicochemical properties of gas and the technical conditions for connection to the gas network, determined by the gas supplier. However, the gas installation in the building should ensure the supply of gaseous fuel to the amount corresponding to the needs of the user and the appropriate pressure on the inlet to the gas appliances. Therefore, in the case of designing a gas installation in buildings accounting for the needs of residents, gas appliances are selected for which type or level of gas consumption should be determined. This process applies to both the flow rate determination of individual devices; in particular, the total flow rates for all gas appliances are installed in the building. However, the load of installation gas pipes is determined differently, due to the fact that flow rate is much lower than if it were to result from the sum of nominal gas consumption by devices of the same type. To calculate maximum gas demand, simultaneity factors should also be considered [9-17]. Due to the different approach for determining these factors required for installations with combi boilers, this paper has made a comparison of the impact of simultaneity factors on the total gas demand.

\section{Review of selected calculation methods}

There are many ways to determine the gas demand for gas appliances installed in multifamily buildings. Each method includes relevant indicators such as: the number of gas appliances and gas customers, nominal gas consumption, correction factors, time of use, etc. Taking into account the above-mentioned factors, the calculation results should be expected at a similar and comparable level. Prior to the commencement of the multi-variant gas demand analysis, the detailed characterisation of the different calculation method should be performed.

\subsection{Method according to German guidelines DVGW-TRGI-86}

A formula for the total maximum gas demand calculation in a residential building usually takes the form $[9,10,12]$ :

$$
V_{h}=\sum V_{g c} \cdot f_{g c}+\sum V_{i w h} \cdot f_{i w h}+\sum V_{g b} \cdot f_{g b} ; \quad \mathrm{m}^{3} / \mathrm{h}
$$

where:

$V_{h} \quad$ - hourly gas demand, $\mathrm{m}^{3} / \mathrm{h}$,

$V_{g c}$ - nominal gas consumption by a gas cooker, $\mathrm{m}^{3} / \mathrm{h}$,

$f_{g c}-$ simultaneity factor for gas cookers,

$V_{i w h}$ - nominal gas consumption by an instantaneous water heater, $\mathrm{m}^{3} / \mathrm{h}$,

$f_{i w h}-$ simultaneity factor for instantaneous water heaters,

$V_{g b} \quad$ nominal gas consumption by a gas boiler, $\mathrm{m}^{3} / \mathrm{h}$,

$f_{g b} \quad-$ simultaneity factor for gas boilers.

For installation equipped with gas combi boilers, the Luxembourg standard states that gas demand for DHW (domestic hot water) needs, with a coefficient equal to 1 , should be taken into account for a single device. However, in the calculations performed in the following sections, one should take simultaneity factors for single-function boilers with the gas demand for heating purposes, omitting the preparation of DHW. Bąkowski [9] has proposed the adoption of simultaneity factors for gas combi boilers as for single-function 
heating boilers, with gas consumption at the maximum boiler power (for domestic hot water preparation).

In the study of the European Copper Institute [11], an additional component (multiplier of nominal gas consumption and simultaneity factor) for a gas combi boiler has been proposed:

$$
V_{h}=\sum V_{g c} \cdot f_{g c}+\sum V_{i w h} \cdot f_{i w h}+\sum V_{g b} \cdot f_{g b}+\sum V_{g c b} \cdot f_{g c b} ; \quad \mathrm{m}^{3} / \mathrm{h}
$$

where:

$V_{g c b}$ - nominal gas consumption by a gas combi boiler, $\mathrm{m}^{3} / \mathrm{h}$,

$f_{g c b}-$ simultaneity factor for gas combi boilers.

Englart and Skrzycki [10] have proposed a corrected factor of simultaneity for this additional component, as follows (3), (4):

$$
\begin{gathered}
V_{h}=\sum V_{g c} \cdot f_{g c}+\sum V_{i w h} \cdot f_{i w h}+\sum V_{g b} \cdot f_{g b}+\sum V_{g c b} \cdot f_{g c b}^{c o r} ; \quad \mathrm{m}^{3} / \mathrm{h} \\
f_{g c b}^{c o r}=\left(\frac{0.858}{n_{g c b}^{0.628}}+0.139\right)
\end{gathered}
$$

where:

$f_{g c b}^{c o r}$ - corrected simultaneity factor for gas combi boilers,

$n_{g c b} \quad$ number of gas combi boilers.

\subsection{Method based on average annual gas demand}

In his previous papers $[9,18]$, Bąkowski presented the method for determining the gas demand. For this purpose, he proposed the following formula:

$$
V_{h}=\frac{Q_{a a}}{h_{a}} \cdot n+\sum V_{S} \cdot n \cdot f_{1} ; \quad \mathrm{m}^{3} / \mathrm{h}
$$

where:

$Q_{a a} \quad$ - average annual gas demand for heating purposes for a single recipient, $\mathrm{m}^{3} /$ year,

$h_{a} \quad$ - annual number of hours of use of the gas installation, $\mathrm{h}$,

$n$ - number of gas recipients,

$\Sigma V_{S}-$ sum of the nominal loads of gas appliances used to prepare meals and domestic hot water, $\mathrm{m}^{3} / \mathrm{h}$.

However, in another paper, Bąkowski [9] has proposed determining the maximum gas demand $V_{h}$, based on two components: the sum of the annual gas consumption for heating purposes connected to the annual number of operating hours of gas-consuming appliances; and maximum hourly gas consumption for hot water and meals preparation purposes, taking into account the coefficients of simultaneity determined by the Zajda formula (6) [15]:

$$
f_{1}=\frac{1}{n^{0.52}}
$$


$f_{1} \quad$ - simultaneity factor of gas consumption for municipal purposes.

The annual gas consumption by the recipient for space heating, can be calculated by the following formula [19]:

$$
Q_{a a}=w_{g} \cdot F \cdot D d\left(t_{b}\right) ; \quad \mathrm{m}^{3} / \text { year }
$$

where:

$w_{g} \quad-$ gas consumption efficiency benchmark for heating purposes, $\mathrm{m}^{3} /\left({ }^{\circ} \mathrm{Cday} \cdot \mathrm{m}^{2}\right)$,

$F \quad-$ heated flat area, $\mathrm{m}^{2}$,

$D d\left(t_{b}\right)$ - annual number of heating degree days referenced to the base temperature $t_{b}$, ${ }^{\circ}$ Cday.

Dopke [19] reports that the value of the gas consumption efficiency benchmark for heating purposes is referenced to the base temperature $t_{b}=18.3^{\circ} \mathrm{C}$ and in new resources should be equal to $w_{g}=0.0032 \mathrm{~m}^{3} /\left({ }^{\circ} \mathrm{Cday} \cdot \mathrm{m}^{2}\right)$. Based on the average number of heating degree days in Poland [2], equal to $\operatorname{Dd}\left(t_{b}\right)=3829$, and well-known heated flats area, one can calculate the average annual gas demand for an individual recipient.

\subsection{Method based on maximum hourly gas demand}

The method discussed in detail manner by Życzyńska [20] consists of determining a maximum hourly gas demand using an average daily gas consumption $E_{d a y}$, taking into account a coefficient of hourly irregularity $N_{h}$ :

$$
V_{h}=\frac{E_{d a y}}{t} \cdot N_{h} ; \quad \mathrm{m}^{3} / \mathrm{h}
$$

where:

$t \quad$ - number of hours within the day of gas consumption, $\mathrm{h}$

$E_{\text {day }} \quad$ - average daily gas consumption, $\mathrm{m}^{3} /$ day

$N_{h} \quad$ - coefficient of hourly irregularity.

This method requires determining an average daily degree day at the base temperature equal to $t_{b}=18^{\circ} \mathrm{C}$ which, in January, can be calculated from the below equation [21]:

$$
\operatorname{Dd}\left(t_{b}\right)=\left(31 \cdot t_{b}+84.16\right) / 31 ; \quad{ }^{\circ} \mathrm{Cday}
$$

The second step is to determine the average annual gas demand using the following formula [4]:

$$
E_{d a y}=w_{T} \cdot F \cdot D d\left(t_{b}\right) ; \mathrm{m}^{3} / \text { day }
$$

where:

$w_{T} \quad$ - total gas consumption efficiency benchmark, $\mathrm{m}^{3} /\left({ }^{\circ} \mathrm{Cday} \cdot \mathrm{m}^{2}\right)$,

$F \quad$ - heated flat area, $\mathrm{m}^{2}$,

$D d\left(t_{b}\right)$ - annual number of heating degree days referenced to the base temperature $t_{b}$, ${ }^{\circ} \mathrm{Cday}$. 
Based on equation (10) and data published by Dopke [19], we can state that in residential buildings total gas consumption efficiency benchmark $w_{T}$ is equal $0.00533 \mathrm{~m}^{3} /\left({ }^{\circ} \mathrm{Cday} \cdot \mathrm{m}^{2}\right)$ (for the base temperature $t_{b}=18.3^{\circ} \mathrm{C}$ ).

One important issue is an assumption of the correct number of hours during the day in which gas consumption was observed. Bąkowski [9] claims that this numbers are equal respectively 12 hours for space heating purposes (which is related to the daily boiler's operating time) and maximum 7 hours for municipal needs. In another paper, Szaflik and Nejranowski [22] concluded that for small plumbing installations (up to 30 sanitary appliances), hot water intake may not occur for even $75 \%$ of daily time.

\subsection{Method developed by Zajda}

This method consists of two categories of recipients using gas for municipal needs (hot water and meals preparation) and non-municipal purposes (individual space heating). In this method the total gas demand can be determined as follows [13, 15]:

$$
V_{h}=V_{1} \cdot n_{1} \cdot f_{1} \cdot \beta_{1}+V_{2} \cdot n_{2} \cdot f_{2} \cdot \beta_{2}
$$

where:

$n \quad-\quad$ number of gas recipients from a given category,

$f \quad-\quad$ simultaneity factor for a given category of recipients,

$V \quad-\quad$ nominal gas consumption for a given category of recipients, $\mathrm{m}^{3} / \mathrm{h}$,

1 - recipients using gas for municipal and leaving purposes,

$2-$ recipients using gas for individual space heating,

$\beta-$ correction factors for gas consumption including non-municipal recipients, $(1.25-2.10)$.

In the case of lack of information about the presence of these recipients, correction factors should be omitted.

For the calculation of simultaneity factors, the following formulas are used $[13,15]$ :

$$
\begin{aligned}
& f_{1}=\frac{0.94}{n_{1}^{0.60}}+0.06 \\
& f_{2}=\frac{0.70}{n_{2}^{0.22}}+0.30
\end{aligned}
$$

\section{Analysis of different gas installation calculation options}

The analysis of different calculation methods for a multi-family residential building was carried out for the following assumptions:

- Apartments specifications:

(a) two M3 apartments with an area of $60 \mathrm{~m}^{2}$, consisting of two rooms, kitchen, hallway, bathroom and toilet,

(b) two M5 apartments with an area of $95 \mathrm{~m}^{2}$, consisting of four rooms, kitchen, hallway, bathroom and toilet.

- Four residential storeys.

- Four apartments on each floor (two M3 and two M5 apartments).

- High-methane natural gas (Group E).

- Two categories of housing equipment for all apartments with gas appliances: 
(a) I Category:

○ Gas cooker with an electric oven $V_{g c}=0.85 \mathrm{~m}^{3} / \mathrm{h}(8 \mathrm{~kW})$,

○ Instantaneous water heater $V_{i w h}=2.60 \mathrm{~m}^{3} / \mathrm{h}(24 \mathrm{~kW})$,

○ Single function gas boiler $V_{g b}=0.60 \mathrm{~m}^{3} / \mathrm{h}(5 \mathrm{~kW})$.

(b) II Category:

○ Gas cooker with an electric oven $V_{g c}=0.85 \mathrm{~m}^{3} / \mathrm{h}(8 \mathrm{~kW})$,

○ Gas combi boiler $V_{g c b}^{\max }=2.60 \mathrm{~m}^{3} / \mathrm{h}(24 \mathrm{~kW})$ (gas demand for domestic hot water preparation), $V_{g c b}^{\min }=0.60 \mathrm{~m}^{3} / \mathrm{h}(5 \mathrm{~kW})$ (gas demand for space heating purposes).

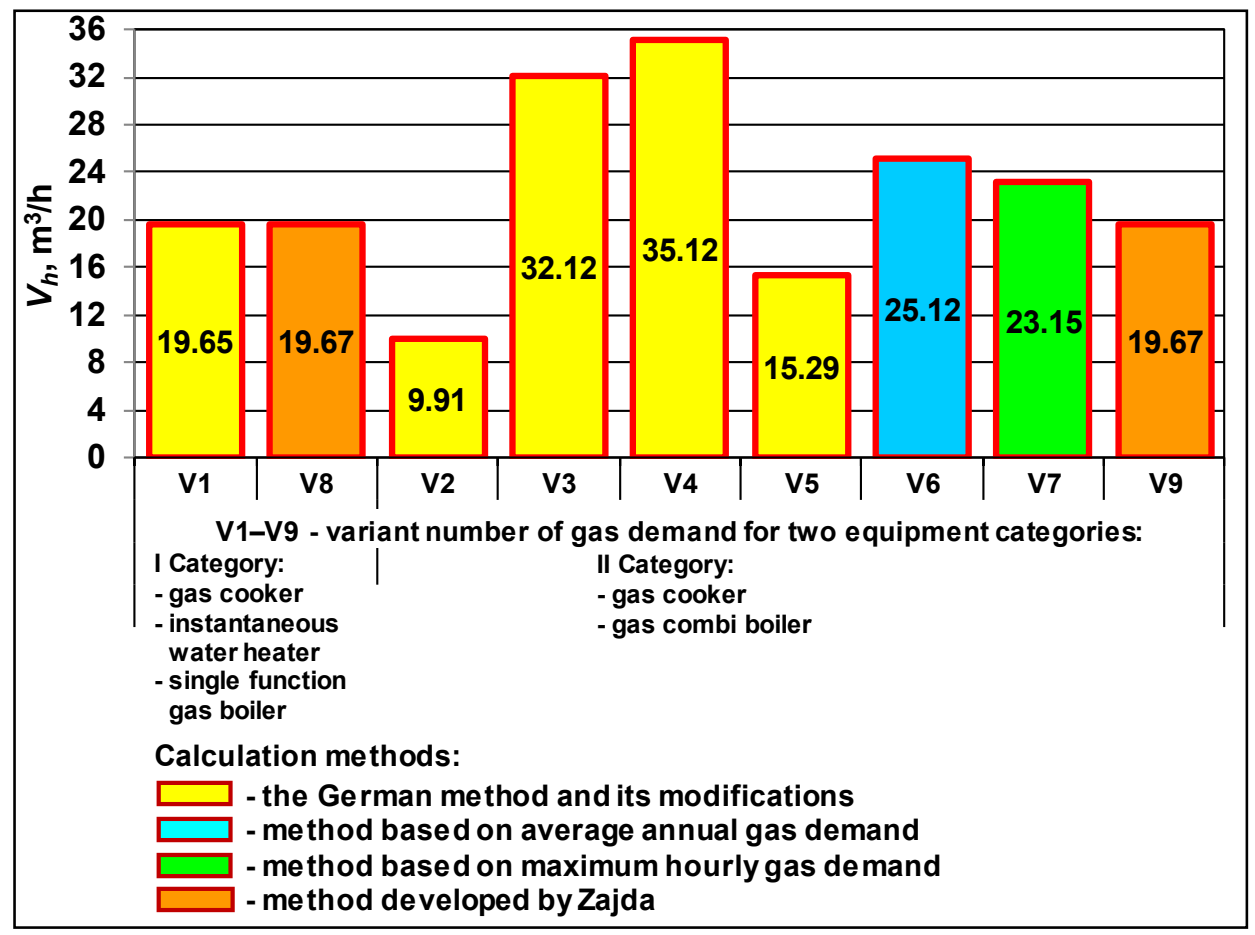

Fig. 1. The comparison of the results of the selected methods of calculation of gas demand.

Table 1. Variant number for German method.

\begin{tabular}{|c|c|c|}
\hline $\begin{array}{c}\text { Variant } \\
\text { number } \\
\text { for } \\
\text { German } \\
\text { method }\end{array}$ & $\begin{array}{c}\text { Number } \\
\text { of } \\
\text { equation }\end{array}$ & Description for gas demand determination \\
\hline $\mathrm{V} 1$ & (1) & Maximum gas flow rate for all devices including factors of simultaneity. \\
\hline $\mathrm{V} 2$ & (1) & $\begin{array}{l}\text { Maximum gas flow rate for the gas cookers and the minimum flow rate } \\
\text { for combi boilers including factors of simultaneity. }\end{array}$ \\
\hline V3 & $(1)$ & \multirow{2}{*}{ Maximum gas flow rate for all devices including factors of simultaneity. } \\
\hline V4 & $(2)$ & \\
\hline V5 & $\begin{array}{l}\text { (3) } \\
\text { (4) }\end{array}$ & $\begin{array}{l}\text { Maximum gas flow rate for all devices including the corrected factor of } \\
\text { simultaneity for combi boilers. }\end{array}$ \\
\hline
\end{tabular}

The gas demand results for two categories of gas equipment (Fig. 1) were obtained on the basis of all the calculation methods described in Section 2. The results included in 
Category I were used only as comparative data in relation to Category II. The Category I includes single function gas boilers and instantaneous water heater, which are an alternative solution for gas combi boilers. A detailed description of the variants based on the German method is provided in Table 1. It should be clearly stated that all the variants of calculations compared concerned the same living and heating needs. The results obtained on gas demand should therefore be at a similar level. Based on the results of two calculation variants (V1 and V8), this rule has been maintained to some extent (Fig. 1). However, significant discrepancies were observed for other variants. The method of calculation of variant V2 is characterised by the lowest gas demand. This is mainly due to the fact that, in this procedure, the heating power demand for DHW preparation has been omitted. On the other hand, variants V3 and V4 represent different values. In these methods, the power demand for the needs of hot water preparation was taken into account but too large values of the simultaneity factors were assumed. Other calculation options (V5-V7, V9) were considered to constitute the most reliable methods because their results were slightly different from the alternative options (V1 and V8).

\section{Conclusions}

Gas combi boilers are an alternative to single function gas boilers and instantaneous water heaters. Currently, they are the most commonly used devices in residential buildings. For this reason, gas combi boilers require an appropriate approach to the determination of gas demand. The use of simultaneity factors for gas combi boilers available in the literature (usually higher than for single function gas boilers) causes systematic overestimation of gas demand. However, the omission of the heating power for the needs of DHW gives unreliable gas demand. In summary, the most reliable calculation methods for the gas demand for the analysed residential building were given.

The work was realized within the allocation No. 0401/0007/17 awarded for Faculty of Environmental Engineering Wroclaw University of Science and Technology by Ministry of Science and Higher Education in years 2017-2018.

\section{References}

1. P.J. Boait, D. Dixon, D. Fan, A. Stafford, Energ. Buildings 54, 160-168 (2012)

2. J. Dopke, Gaz, Woda i Technika Sanitarna 3, 2-9 (2007)

3. P. Jones, X.J. Li, E. Perisoglou, J. Pattersonings, Energ. Buildings 154, 335-342 (2017)

4. J. Szoplik, Gaz, Woda i Technika Sanitarna 1, 2-6 (2010)

5. A.U. Atmaca, A. Erek, H.M. Altay, Appl. Therm. Eng. 82, 129-140 (2015)

6. A.U. Atmaca, A. Erek, H.M. Altay, Energ. Buildings 127, 1043-1056 (2016)

7. C. M. Haissig, M. Woessner, HVAC\&R Research 6 (2), 117-134 (2000)

8. Obwieszczenie Ministra Infrastruktury i Rozwoju z dnia 17 lipca 2015 r. w sprawie ogtoszenia jednolitego tekstu rozporzadzenia Ministra Infrastruktury $w$ sprawie warunków technicznych, jakim powinny odpowiadać budynki i ich usytuowanie (Dz. U Nr Poz. 1422)

9. K. Bąkowski, Sieci $i$ instalacje gazowe (Wydawnictwa Naukowo-Techniczne, Warszawa, 2007)

10. S. Englart, M. Skrzycki, Gaz, Woda i Technika Sanitarna 1, 2-7 (2016) 
11. Instalacje wodociagowe, ogrzewcze $i$ gazowe na paliwo gazowe, chłodnicze, klimatyzacyjne, gazów medycznych oraz próżni wykonane z rur miedzianych i stopów miedzi. Wytyczne stosowania i projektowania (Europejski Instytut Miedzi, 2013)

12. Journal Officiel du Grand-Duché de Luxembourg. Recueil de Legislation, Installations de combustion alimentees en gaz ( $\mathrm{A}-\mathrm{N}^{\circ} 104,17$ octobre 2000)

13. K. Kogut, K. Bytnar, Obliczanie sieci gazowych. Omówienie parametrów wymaganych do obliczeń, tom 1 (Uczelniane wydawnictwo naukowo-techniczne, Kraków, 2007)

14. R. Zajda, Projektowanie sieci gazowych. Schematy obliczeniowe gazociagów (Centrum Szkolenia Gazownictwa, Warszawa, 2001)

15. R. Zajda, B. Tymiński, Instalacje i urzadzenia gazowe. Projektowanie, wykonywanie, odbiór i eksploatacja (Centrum Szkolenia Gazownictwa PGNiG, Warszawa, 1999)

16. R. Zajda, Z. Gebhardt, Instalacje gazowe oraz lokalne sieci gazów plynnych. Projektowanie - wykonywanie - eksploatacja (COBO-Profil, Warszawa, 1995)

17. S. Englart, A. Jedlikowski, Gaz, Woda i Technika Sanitarna 9, 350-354 (2017)

18. K. Bąkowski, Gaz, Woda i Technika Sanitarna 11, 359-362 (1994)

19. J. Dopke, Gaz, Woda i Technika Sanitarna 1, 5-9 (2009)

20. A. Życzyńska, Gaz, Woda i Technika Sanitarna 3, 2-5 (2009)

21. J. Dopke, http://www.cire.pl/pokaz-pdf\%252Fpliki\%252F2\%252Foblicz_stopniodnigrzania.pdf

22. W. Szaflik, J. Nejranowski, Gaz, Woda i Technika Sanitarna 11, 495-497 (2012) 